\title{
Efektivitas Pembelajaran Remedial Secara Daring pada Masa Belajar dari Rumah di SMA Negeri 1 Majene
}

\author{
Yanti $^{1}$, Firman $^{2 *}$, Arlinda Puspita Sari ${ }^{3}$ \\ ${ }_{1,2,3}$ Universitas Sulawesi Barat; \\ e-mail: ${ }^{1}$ yantisaenong98@gmail.com, ${ }^{2 *}$ firman@ @unsulbar.ac.id, ${ }^{3}$ arlindapuspitasari@unsulbar.ac.id
}

\begin{abstract}
Abstrak
Proses pembelajaran dari rumah membawa berbagai dampak pada hasil belajar peserta didik, salah satunya yaitu tidak tercapainya nilai ketuntasan minimum sehingga diperlukan pembelajaran remedial. Penelitian ini adalah penelitian deskriptif kuantitatif yang bertujuan untuk mengetahui efektivitas pembelajaran remedial yang dilaksanakan secara daring selama periode belajar dari rumah di SMA Negeri 1 Majene. Efektifitas pembelajaran ditinjau dari dua aspek yakni hasil belajar dan proses pembelajaran. Analisis data hasil belajar menunjukkan nilai Normalized Gain (N Gain) sebesar 0.55 yang berarti pembelajaran remedial efektif dalam meningkatkan hasil belajar. Hasil analisis angket respon guru dan peserta didik secara berturut-turut adalah 71,67\% dan 76,55\% yang berarti bahwa baik guru dan peserta didik menilai bahwa pembelajaran remedial secara daring efektif untuk dilaksanakan. Hal ini menunjukkan bahwa pembelajaran remedial secara daring di SMA Negeri 1 Majene efektif dari sudut pandang proses dan hasil pembelajaran.
\end{abstract}

Kata kunci-3-5 pembelajaran daring, remedial, BDR

\section{PENDAHULUAN}

Lockdown dan pembatasan sosial akibat penyebaran pandemi Covid-19 mengakibatkan penutupan fasilitas pendidikan termasuk sekolah dan perguruan tinggi di berbagai negara termasuk Indonesia. Hal ini menyebabkan pergeseran paradigma dan perubahan cara pendidik dalam melaksanakan pembelajaran. Peralihan sistem pembelajaran tatap muka menjadi pembelajaran dalam jaringan (daring) secara mendadak menuntut guru untuk mampu beradaptasi secara cepat meski hanya dengan sedikit persiapan (Pokhrel \& Chhetri, 2021).

Pelaksanaan pembelajaran daring menimbulkan tantangan tersendiri. Ada beberapa masalah yang timbul selama pembelajaran daring, misalnya sulitnya melaksanakan pembelajaran aktif akibat terbatasnya interaksi antara guru dan peserta didik (Hill \& Fitzgerald, 2020), adanya kerugian peserta didik terkait penilaian hasil belajar (Sari et al., 2021) serta kendala-kendala teknis seperti terbatasnya penguasaan teknologi, penambahan biaya data internet, serta pekerjaan tambahan bagi orang tua untuk mendampingi anak belajar (Purwanto et al., 2020).

Berbagai kendala yang muncul dalam pembelajaran daring pada gilirannya memiliki dampak pada hasil belajar peserta didik. Firman et al., (2021) mengungkapkan bahwa ketika mengikuti pembelajaran daring, perhatian peserta didik gampang teralihkan sehingga mereka kesulitan memahami materi pelajaran dengan baik. Kuhfeld \& Tarasawa (2020) mengestimasikan bahwa potensi munculnya learning loss pada peserta didik akibat pandemi Covid-19 sangat besar.

Studi pendahuluan yang dilakukan di SMAN 2 Majene menunjukkan bahwa selama masa belajar dari rumah akibat pandemi Covid-19 yang dilaksanakan dalam format pembelajaran daring, angka ketidaktuntasan peserta didik terbilang cukup tinggi. Dari analisis dokumen hasil belajar, diperoleh informasi bahwa rata-rata peserta didik yang tidak tuntas adalah $40 \%$. Sebagai langkah kuratif terhadap permasalahan ini, maka dilakukan pembelajaran remedial.

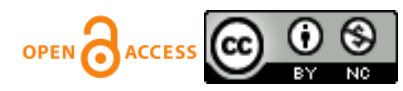


Istilah pembelajaran remedial pada mulanya adalah kegiatan mengajar untuk anak luar biasa yang mengalami berbagai hambatan (sakit). Namun, dewasa ini pengertian sudah berkembang, sehingga anak yang normal pun memerlukan pelayanan pembelajaran remedial (Guntur, 2009). Pembelajaran remedial secara umum diartikan sebagai upaya yang berkaitan dengan perbaikan pada diri orang atau suatu pemberian bimbingan khusus pada anak sekolah terutama ditujukan kepada peserta didik yang mengalami hambatan dalam proses belajar (Slamet, 2015).

Tujuan pembelajaran remedial secara umum adalah membantu peserta didik mencapai hasil belajar sesuai dengan tujuan pembelajaran yang ditetapkan dalam kurikulum (Sari, 2016). Tujuan lain dari pemberian pengajaran remedial pada peserta didik yaitu (1) memahami dirinya, khususnya yang menyangkut prestasi dan kesulitannya (2) mengubah dan memperbaiki cara-cara belajar yang lebih baik sesuai dengan jenis kesulitannya (3) memilih materi dan fasilitas belajar secara tepat untuk mengatasi kesulitan belajar (4) mengatasi hambatan-hambatan belajar yang menjadi latar belakang kesulitannya (5) mengembangkan sikap dan kebiasaan baru yang dapat mendorong tercapainya hasil belajar yang baik (6) Melaksanakan tugas-tugas belajar yang diberikan (Mutmainah et.al., 2017).

Sebelum pandemi Covid-19, pembelajaran remedial biasanya diberikan dalam bentuk bimbingan tatap muka, akan tetapi selama masa belajar dari rumah akibat pandemi Covid-19, pembelajaran remedial dilaksanakan secara daring dengan bantuan aplikasi pesan instan atau layanan-layanan konferensi video online. Berdasarkan hal tersebut, maka dirumuskan pertanyaan penelitian sebagai berikut: bagaimana efektivitas pembelajaran remedial secara daring selama periode belajar dari rumah ditinjau dari hasi belajar dan proses pembelajaran?.

\section{METODE PENELITIAN}

Penelitian ini adalah penelitian deskriptif dengan pendekatan kuantitatif yang bertujuan untuk mengetahui efektivitas pembelajaran remedial secara daring selama periode belajar dari rumah. Subjek penelitian ini adalah 38 siswa kelas X IPA SMAN 2 Majene yang mengikuti pembelajaran remedial untuk mata pelajaran biologi pada semester ganjil tahun ajaran 2020/2021. Peserta remedial adalah siswa yang memperoleh nilai hasil belajar di bawah nilai Kriteria Ketuntasan Minimal (KKM) yaitu 70. Efektivitas pembelajaran remedial ditinjau dari dua aspek, yakni dari segi hasil belajar dan dari segi proses pembelajaran. Efektivitas pembelajaran remedial dari segi hasil ditinjau dari peningkatan hasil belajar yang dihitung menggunakan analisis Normalized Gain ( $N$ Gain). Interpretasi nilai $N$ Gain yang diadaptasi dari (Nismalasari et al., 2016) dapat dilihat pada Tabel 1 berikut.

Tabel 1. Interpretasi N Gain

\begin{tabular}{ccc}
\hline N Gain & Peningkatan & Interpretasi \\
\hline $0,70 \leq \mathrm{g} \leq 100$ & Tinggi & Sangat efektif \\
$0,30 \leq \mathrm{g}<0,70$ & Sedang & Efektif \\
$0,00 \leq \mathrm{g} \leq 0,30$ & Rendah & Cukup efektif \\
$\mathrm{g}=0,00$ & Tidak Terjadi Peningkatan & Tidak efektif \\
$-1,00 \leq \mathrm{g} \leq 0,00$ & Terjadi Penurunan & Sangat tidak efektif \\
\hline
\end{tabular}

Efektivitas pembelajaran remedial dari segi proses diukur menggunakan angket respon terhadap pembelajaran remedial yang diisi oleh 38 peserta didik yang mengikuti pembelajaran remedial serta 1 orang guru pengampu mata pelajaran biologi. Interpretasi hasil analisis angket diadaptasi dari (Prasetyo \& Jannah, 2007) dapat dilihat pada Tabel 2 berikut. 
https://jurnal.unsulbar.ac.id/index.php/saintifik

Tabel 2. Pedoman Interpretasi Respon terhadap Pembelajaran Remedial

\begin{tabular}{cc}
\hline Skor $(\%)$ & Interpretasi \\
\hline $80-100$ & Sangat efektif \\
$60-79$ & Efektif \\
$40-59$ & Cukup efektif \\
$20-39$ & Kurang efektif \\
$0-19$ & Sangat tidak efektif \\
\hline
\end{tabular}

\section{HASIL DAN PEMBAHASAN}

Pembelajaran remedial merupakan usaha yang ditempuh untuk memperbaiki hasil belajar peserta didik, terutama yang tidak tuntas dalam memenuhi kompetensi pembelajaran yang dituntut suatu mata pelajaran. Dalam penelitian ini, pembelajaran remedial dilakukan dengan memberikan pelajaran serta tugas tambahan kepada peserta didik yang tidak tuntas belajar. Namun akibat kebijakan belajar dari rumah yang diterapkan selama masa pandemi Covid-19, maka pembelajaran remedial dilaksanakan secara daring melalui aplikasi WhatsApp dan Zoom.

Secara umum, gambaran hasil belajar peserta didik yang mengikuti remedial dapat dilihat pada Tabel 3 dan Tabel 4 sebagai berikut.

Tabel 3. Analisis Deskriptif Hasil Belajar Sebelum Remedial dan Setelah Remedial

\begin{tabular}{cccccccc}
\hline Hasil Belajar & N & Range & Minimum & Maximum & Mean & $\begin{array}{c}\text { Std. } \\
\text { Deviation }\end{array}$ & Variance \\
\hline $\begin{array}{c}\text { Sebelum } \\
\text { Remedial }\end{array}$ & 38 & 40,00 & 20,00 & 60,00 & 45,26 & 10,32 & 106,68 \\
$\begin{array}{c}\text { Setelah } \\
\text { Remedial }\end{array}$ & 38 & 30,00 & 60,00 & 90,00 & 75,89 & 7,54 & 56,85 \\
\hline
\end{tabular}

Tabel 4. Deskripsi Hasil Belajar Peserta Didik

\begin{tabular}{ccccc}
\hline $\begin{array}{c}\text { Interval Nilai } \\
\text { Hasil Belajar }\end{array}$ & Kategori & $\begin{array}{c}\text { Sebelum } \\
\text { Remedial }(\boldsymbol{\%})\end{array}$ & $\begin{array}{c}\text { Setelah } \\
\text { Remedial }(\boldsymbol{\%})\end{array}$ & Keterangan \\
\hline $\mathbf{9 0 - 1 0 0}$ & Sangat Tinggi & 0 & 7,90 & Tuntas \\
$\mathbf{7 0 - 8 9}$ & Tinggi & 0 & 86,84 & Tuntas \\
$\mathbf{5 0 - 6 9}$ & Sedang & 52,63 & 5,26 & Tidak Tuntas \\
$\mathbf{3 0 - 4 9}$ & Rendah & 44,74 & 0 & Tidak Tuntas \\
$\mathbf{0 - 2 9}$ & Sangat Rendah & 2,63 & 0 & Tidak Tuntas \\
\hline
\end{tabular}

Table 4 menunjukkan bahwa terjadi peningkatan hasil belajar peserta didik yang mengikuti pembelajaran remedial. Dari total 38 peserta didik yang mengikuti remedial, hanya 2 orang $(5,26 \%)$ yang tidak tuntas belajar, sementara 36 lainnya $(94,74 \%)$ dinyatakan tuntas belajar. Peningkatan hasil belajar ini menunjukkan bahwa pembelajaran remedial mampu membantu siswa dalam memperbaiki hasil belajarnya. 
Hasil analisis $N$ Gain secara klasikal menunjukkan nilai 0,55 yang jika diinterpretasi sesuai informasi pada tabel 1 menunjukkan bahwa pembelajaran remedial yang dilaksanakan secara daring mampu meningkatkan hasil belajar peserta didik. Hal ini berarti bahwa pembelajaran remedial secara daring efektif jika ditinjau dari aspek hasil belajar peserta didik.

Menurut Jamildayanti (2019) pembelajaran remedial memiliki pengaruh yang positif terhadap hasil belajar siswa. Selain itu, pembelajaran remedial sebagai usaha yang ditempuh untuk meningkatkan kualitas penguasaan peserta didik terhadap materi pelajaran (Lidi, 2018), terbukti mampu meningkatkan ketuntasan klasikal peserta didik (Setiawan et.al;., 2017).

Hasil analisis angket respon guru dan peserta didik secara berturut-turut adalah 71,67 dan 76,55 yang berarti bahwa baik guru maupun peserta didik menilai bahwa pembelajaran remedial secara daring efektif untuk dilaksanakan. Gambaran respon guru dan peserta didik untuk setiap indikator pernyataan angket dapat dilihat pada Tabel 5 sebagai berikut.

Tabel 5. Respon guru dan peserta didik terhadap pembelajaran remedial daring

\begin{tabular}{ccccc}
\hline Indikator & $\begin{array}{c}\text { Skor Respon } \\
\text { Peserta Didik }\end{array}$ & Keterangan & $\begin{array}{c}\text { Skor Respon } \\
\text { Guru }\end{array}$ & Keterangan \\
\hline $\begin{array}{c}\text { Dukungan perangkat } \\
\text { dan jaringan } \\
\begin{array}{c}\text { Kesesuaian materi } \\
\text { remedial dengan } \\
\text { kesulitan belajar } \\
\text { peserta didik }\end{array}\end{array} \quad 77,50$ & Efektif & 69,22 & Efektif \\
$\begin{array}{c}\text { Media pembelajaran } \\
\text { remedial }\end{array}$ & 81,23 & Sangat efektif & 80,05 & Sangat efektif \\
Aktivitas peserta didik & 73,44 & Efektif & 71,56 & Efektif \\
\hline
\end{tabular}

Berdasarkan Tabel 5 di atas dapat dilihat bahwa secara umum pembelajaran remedial efektif jika ditinjau dari segi proses. Peserta didik maupun guru memberikan respon yang positif terhadap pembelajaran remedial secara daring. Pembelajaran yang dilaksanakan menggunakan aplikasi pesan instan WhatsApp dan layanan video konferensi Zoom menjadi alternatif pembelajaran selama masa belajar dari rumah akibat pandemi Covid-19. Pemilihan media pembelajaran ini ditanggapi dengan baik oleh peserta didik karena mudah digunakan dan dapat diakses dari rumah masing-masing menggunakan telepon pintar dan/atau laptop.

Kemampuan telepon pintar dan laptop mengkases internet mengungkinkan peserta didik untuk mengikuti pembelajaran yang dilaksanakan kelas virtual, aplikasi konferensi video, serta layanan-layanan pembelajaran daring lainnya (Gikas \& Grant, 2013; Chan et al., 2015; Gökçearslan et al., 2016) Telepon pintar dan laptop dengan dukungan jaringan internet memungkinkan peserta didik mengikuti pembelajaran dari rumah masing-masing. Peserta didik juga dapat memanfaatkan fitur penyimpanan gawai tersebut untuk menyimpan materi dan tugas sehingga mereka dapat membaca dan mengerjakannya kapan saja (Firman \& Rahayu, 2020).

Pemilihan materi pembelajaran remedial dilakukan oleh guru menyesuaikan dengan kompetensi yang tidak mampu dicapai oleh peserta didik pada pembelajaran sebelumnya. Masing-masing peserta didik mendapatkan materi pembelajaran yang spesifik sehingga mereka dapat fokus untuk mempelajari dan menguasai kompetensi-kompetensi yang belum mereka kuasai.

Pembelajaran remedial pada dasarnya merupakan langkah kuratif untuk membantu peserta didik yang mengalami kesulitan belajar (Karyanto, 2012). Peserta didik yang mengikuti remedial mendapatkan perlakuan sesuai dengan kesulitan belajar yang dialaminya (Waruwu, 2020). Jika peserta didik gagal pada satu kompetensi dasar (KD) tertentu, maka KD itulah yang dibahas dalam pembelajaran remedial.

Meski mendapat respon positif dari guru dan peserta didik, namun pembelajaran remedial secara daring juga memiliki tantangan sendiri. Banyak peserta didik yang tidak memiliki akses WiFi di rumah sehingga mereka bergantung pada jaringan internet seluler. Hal ini mengharuskan mereka untuk mengeluarkan dana tambahan untuk membeli paket data internet yang ditawarkan oleh berbagai provider 
https://jurnal.unsulbar.ac.id/index.php/saintifik

seluler. Konektivitas internet yang tidak stabil juga mengganggu peserta didik dalam mengikuti pembelajaran terutama yang dilaksanakan menggunakan aplikasi Zoom.

Masih terdapat $27,22 \%$ wilayah Sulawesi Barat dengan penerimaan sinyal seluler yang lemah. Kondisi ini menghambat peserta didik yang tinggal di wilayah tersebut untuk mengikuti pembelajaran online. Selain itu, besarnya kuota data internet yang diperlukan untuk mengakses pembelajaran online terutama yang dilaksanakan menggunakan layanan konferensi video membuat peserta didik harus mengeluarkan biaya tambahan untuk membeli kuota data (Firman \& Rahayu, 2020).

Hambatan lain yang juga dialami oleh guru yakni saat mengajar melalui Zoom dirasa tidak nyaman karena sering terjadi delay respon dari peserta didik terutama ketika jaringan internet sedang mengalami gangguan. Selain itu, mengajar beberapa kelas secara berturut-turut menggunakan Zoom membuat guru mengalami Zoom fatigue. (Firman et al., 2021) menjelaskan bahwa konferensi video membuat penggunanya berkonsentrasi lebih keras dibandingkan ketika melakukan pertemuan secara tatap muka. Ketika melakukan panggilan video, kita membutuhkan energi ekstra untuk bekerja keras dalam memproses informasi-informasi visual dan nonverbal seperti ekspresi, intonasi dan bahasa tubuh.

\section{KESIMPULAN}

Berdasarkan hasil penelitian yang telah dilakukan diperoleh fakta bahwa terjadi peningkatan hasil belajar peserta didik yang sebelumnya tidak tuntas setelah menjalani proses pembelajaran remedial secara daring. Selain itu, guru dan peserta didik juga memberikan respon positif terhadap pelaksanaan pembelajaran remedial tersebut. Sehingga dapat disimpulkan bahwa pembelajaran remedial secara daring selama periode belajar dari rumah efektif dilaksanakan di SMA Negeri 1 Majene baik dari segi proses maupun hasil pembelajaran.

\section{DAFTAR PUSTAKA}

Chan, N. N., Walker, C., \& Gleaves, A. (2015). An Exploration of Students' Lived Experiences of Using Smartphones in Diverse Learning Contexts Using A Hermeneutic Phenomenological Approach. Computers and Education. https://doi.org/10.1016/j.compedu.2014.11.001

Firman, F., \& Rahayu, S. (2020). Pembelajaran Online di Tengah Pandemi Covid-19. Indonesian Journal of Educational Science (IJES). https://doi.org/10.31605/ijes.v2i2.659

Firman, Puspita Sari, A., \& Firdaus. (2021). Aktivitas Mahasiswa dalam Pembelajaran Daring Berbasis Konferensi Video: Refleksi Pembelajaran Menggunakan Zoom dan Google Meet. Indonesian Journal of Educational Science (IJES), https://ojs.unsulbar.ac.id/index.php/ijes/article/view/969

Gikas, J., \& Grant, M. M. (2013). Mobile Computing Devices in Higher Education: Student Perspectives on Learning with Cellphones, Smartphones \& Social Media. Internet and Higher Education. https://doi.org/10.1016/j.iheduc.2013.06.002

Gökçearslan, Ş., Mumcu, F. K., Haşlaman, T., \& Çevik, Y. D. (2016). Modelling Smartphone Addiction: The Role of Smartphone Usage, Self-Regulation, General Self-Efficacy and Cyberloafing in University Students. Computers in Human Behavior. https://doi.org/10.1016/j.chb.2016.05.091

Hill, K., \& Fitzgerald, R. (2020). Student Perspectives of The Impact Of COVID-19 On Learning. All Ireland Journal of Higher Education, 12(2). https://ojs.aishe.org/index.php/aishe-j/article/view/459

Karyanto, U. B. (2012). Strategi Pembelajaran Remedial dan Implementasinya dalam Pembelajaran | Forum $\begin{array}{lllll}\text { Tarbiyah. Forum } & \text { Tarbiyah, } & \text { hittp://e- }\end{array}$ journal.iainpekalongan.ac.id/index.php/forumtarbiyah/article/view/25/0

Kuhfeld, M., \& Tarasawa, B. (2020). Collaborative For Student Growth. In NWEA. NWEA. 121 NW Everett Street, Portland, OR 97209. Tel: 503-624-1951; Fax: 503-639-7873; Web site: http://nwea.org.

Lidi, M. W. (2018). Pembelajaran Remedial Sebagai Suatu Upaya Dalam Mengatasi Kesulitan 
https://jurnal.unsulbar.ac.id/index.php/saintifik

Belajar. FOUNDASIA, 9(1).

Mutmainah, M., Irnidayanti, Y., \& Puspitaningrum, R. (2015). Penerapan Program Remedial Dalam Pembelajaran Biologi di Sekolah Menengah Atas. PARAMETER: Jurnal Pendidikan Universitas Negeri Jakarta, 27(2), 187-192.

Nismalasari, N., Santiani, S., \& Rohmadi, M. (2016). Penerapan Model Pembelajaran Learning Cycle Terhadap Keterampilan Proses Sains Dan Hasil Belajar Siswa Pada Pokok Bahasan Getaran Harmonis. Edu Sains: Jurnal Pendidikan Sains Dan Matematika, 4(2). https://doi.org/10.23971/EDS.V4I2.511

Pokhrel, S., \& Chhetri, R. (2021). A Literature Review on Impact of COVID-19 Pandemic on Teaching and Learning. Higher Education for the Future, 8(1), 133-141. https://doi.org/10.1177/2347631120983481

Prasetyo, Bambang., \& Jannah, Lina Miftahul. (2007). Metode Penelitian Kuantitatif Teori dan Aplikasi. Jakarta: PT Raja Grafindo Persada.

Purwanto, A., Pramono, R., Asbari, M., Budi Santoso, P., Mayesti Wijayanti, L., Chi Hyun, C., \& Setyowati Putri, R. (2020). UNIVERSITAS MUHAMMADIYAH ENREKANG Studi Eksploratif Dampak Pandemi COVID-19 Terhadap Proses Pembelajaran Online di Sekolah Dasar. In EduPsyCouns: Journal of Education, Psychology and Counseling (Vol. 2, Issue 1). https://ummaspul.ejournal.id/Edupsycouns/article/view/397

Sari, R. K. (2016). Pelaksanaan Pengajaran Remedial Pada Mata Pelajaran Matematika Di Kelas Ii Sd N 1 Sedayu. BASIC EDUCATION, 5(14), 1-362.

Sari, R. P., Tusyantari, N. B., \& Suswandari, M. (2021). Dampak Pembelajaran Daring Bagi Siswa Sekolah Dasar Selama Covid-19. Prima Magistra: Jurnal Ilmiah Kependidikan, 2(1), 9-15. https://doi.org/10.37478/jpm.v2i1.732

Slamet, S. (2015). Pembelajaran Remedial untuk Meningkatkan Ketuntasan Belajar Siswa (Studi Kasus Siswa Kelas VI SDN Genengan 2 pada Pembelajaran Matematika FPB dan KPK). An-Nuha: Jurnal Kajian Islam, Pendidikan, Budaya Dan Sosial, 2(1), 97-117. http://ejournal.staimadiun.ac.id/index.php/annuha/article/view/41

Waruwu, T. (2020). IDENTIFIKASI KESULITAN BELAJAR PADA PEMBELAJARAN IPA DAN PELAKSANAAN PEMBELAJARAN REMEDIAL. JURNAL EDUCATION AND DEVELOPMENT, 8(2), 285-285. http://journal.ipts.ac.id/index.php/ED/article/view/1697. 